\title{
Description of Two Morphotypes of Peptostreptococcus micros
}

\author{
P. J. vAN DALEN, ${ }^{1}$ T. J. M. VAN STEENBERGEN,${ }^{1}$ M. M. COWAN,${ }^{2}$ H. J. BUSSCHER,${ }^{2}$ \\ AND J. DE GRAAFF ${ }^{1 *}$ \\ Department of Oral Microbiology, Academic Centre for Dentistry Amsterdam, van der Boechorststraat 7, \\ 1081 BT Amsterdam, ${ }^{1}$ and Materia Technica, University of Groningen, Groningen, ${ }^{2}$ The Netherlands
}

\begin{abstract}
Peptostreptococcus micros is often isolated from abscesses in several parts of the human body. The oral cavity is considered the natural habitat for the species, which has been implicated as a periodontal pathogen. In plaque samples from periodontitis patients we observed the presence of a rough morphotype of $P$. micros in addition to the previously recognized smooth morphotype. The rough morphotype has not been described previously. Both morphotypes are frequently isolated simultaneously from the same patient. In this paper strains of both morphotypes are described. The smooth morphotype, represented by the type strain, grew as small, dome-shaped, bright white, nonhemolytic colonies. The rough morphotype grew as equally white dry colonies which were hemolytic and had wrinkled edges. DNA-DNA reassociation studies revealed homology at the species level between the two morphotypes; in addition, no differences in physiological characteristics were observed when the organisms were tested with API-32A and API-ZYM kits. The rough cells had long, thin fibrillar structures outside the cell envelope when they were stained negatively for electron microscopy. In the smooth morphotype these structures were not present. The sodium dodecyl sulfate-polyacrylamide gel electrophoresis profiles of whole-cell extracts were different for the two morphotypes. In xylene-water phase partition studies, the smooth morphotype was found to be hydrophobic, whereas the rough morphotype was found to be relatively hydrophilic. The distinct morphotypes were stable on blood agar; however, the rough morphotype changed to a nonfibrillar type with a smooth colony morphology after repeated subculturing in broth.
\end{abstract}

Gram-positive anaerobic cocci are commonly found on mucous membranes of the oral cavity, the intestines, and the vagina. These bacteria are isolated from a variety of human abscesses as well. Frequently, the strains isolated belong to the genus Peptostreptococcus. The presence of Peptostreptococcus micros is not restricted to a particular part of the human body. Polymicrobial pulmonary and cerebral abscesses $(9,12,24)$, as well as female genital tract infections (7), can contain high percentages of $P$. micros. It is thought that the natural habitat of this species is the oral cavity (14). Plaque of healthy individuals contains low percentages of this bacterium. It is isolated more often and in increased percentages from patients with periodontitis (18). A correlation in patients has been reported between poor response to periodontal therapy and the percentage of $P$. micros present in the total cultivable anaerobic flora (17). Furthermore, the presence of the microorganism has been related to active sites of periodontitis $(4,30)$, to endodontic lesions, and to human immunodeficiency virus-related periodontitis $(3,25$, $26,36)$. For these reasons $P$. micros has been implicated as a periodontal pathogen (27).

$P$. micros usually forms smooth colonies. In samples obtained from periodontitis patients, we frequently isolated a rough morphotype of $P$. micros as well. In this paper we describe the results of a descriptive study of the two morphotypes. Strains representing both morphotypes are described on the basis of the results of electron microscopy studies and studies on DNA-DNA homology, hydrophobicity, biochemical reactions, interactions with erythrocytes, and sodium dodecyl sulfate (SDS)-polyacrylamide gel electrophoresis (PAGE) profiles.

\footnotetext{
* Corresponding author.
}

\section{MATERIALS AND METHODS}

Microorganisms. A total of 39 strains, including 15 isolates of the rough morphotype, 19 strains of the smooth morphotype, and 5 strains of other Peptostreptococcus species, were examined in this study. The Peptostreptococcus magnus strain, the Peptostreptococcus anaerobius strains, and five $P$. micros strains were kindly provided by T. Ezaki, Gifu, Japan, and S. Persson, Umeå, Sweden. Our own isolates were obtained from subgingival plaque samples from periodontitis patients. The bacterial strains were all cultivated on blood agar plates (Oxoid no. 2 agar supplemented with $5 \%$ defibrinated horse blood, $5 \mathrm{mg}$ of hemin per liter, and $1 \mathrm{mg}$ of menadione per liter) incubated in $80 \% \mathrm{~N}_{2}-10 \%$ $\mathrm{CO}_{2}-10 \% \mathrm{H}_{2}$ at $37^{\circ} \mathrm{C}$.

Strains were identified on the basis of Gram staining, anaerobic growth, and the results of biochemical reactions, for which ATB-32A and API-ZYM kits (Analytab Products, Montalieu-Vercieu, France) were used. These kits were used according to the recommendations of the manufacturer. The stability of the morphotypes was tested by repeated subculturing, both on blood agar plates and in broth (Schaedler broth; BBL Microbiology Systems, Cockeysville, Md.) in an anaerobic glove box (Forma Scientific, Marietta, Ohio).

DNA isolation. Bacterial strains (four strains of the smooth morphotype and five strains of the rough morphotype) were inoculated into $100-\mathrm{ml}$ portions of Schaedler broth and incubated in an anaerobic glove box for $48 \mathrm{~h}$ without shaking. The cells were harvested by centrifugation at 2,000 $\times g$ for $15 \mathrm{~min}$ at $4^{\circ} \mathrm{C}$. Then the cells were washed twice in TES (10 mM Tris, $5 \mathrm{mM}$ EDTA, $50 \mathrm{mM} \mathrm{NaCl}$; pH 8.0) and finally resuspended in $1 \mathrm{ml}$ of the same buffer. Each suspension was ultrasonically treated for $5 \mathrm{~s}$ at the maximum power setting with an MSE Soniprep 150 apparatus. The cells were then treated with lysozyme $\left(1 \mathrm{mg} / \mathrm{ml}, 1 \mathrm{~h}, 37^{\circ} \mathrm{C}\right)$, proteinase $\mathrm{K}\left(250 \mu \mathrm{g} / \mathrm{ml}, 1 \mathrm{~h}, 37^{\circ} \mathrm{C}\right)$, and $\operatorname{SDS}\left(1 \%, 16 \mathrm{~h}, 60^{\circ} \mathrm{C}\right)$ in the 
presence of RNase $(0.5 \mu \mathrm{g} / \mathrm{ml})$. The DNA was isolated by two phenol-chloroform extractions, two chloroform-isoamyl alcohol extractions, an ether extraction, and RNase treatment. After this, the DNA was purified by two phenolchloroform extractions and two chloroform-isoamyl alcohol extractions and ethanol precipitation. The DNA was washed in ethanol, vacuum dried, and dissolved in $100 \mu \mathrm{l}$ of $\mathrm{H}_{2} \mathrm{O}$. The DNA of Bacteroides fragilis was kindly provided by $\mathrm{B}$. Otto, Amsterdam, The Netherlands.

A mini agarose gel $(0.8 \%$ agarose in $0.04 \mathrm{M}$ Tris-acetate$0.001 \mathrm{M}$ EDTA [pH 8.0]) was used to check the integrity of the DNA. The DNA concentration was calculated from the optical density at $260 \mathrm{~nm}$.

Preparation of labelled DNA. DNAs from the type strain of $P$. micros (ATCC 33270) and a representative rough strain (HG 1439) were labelled by using $\left[{ }^{3} \mathrm{H}\right] \mathrm{dTTP}$ (NEN Research Products, Du Pont, Dreiech, Germany) and a randomprimed DNA labelling kit (Boehringer, Mannheim, Germany). A total of $30 \mathrm{ng}$ of DNA was labelled according to the recommendations of the manufacturer. The remaining single nucleotides were removed from the labelled DNA by using Quick Spin columns containing Sephadex G-50 (Boehringer). Samples containing $1 \mu$ l of labelled DNA were suspended in $2 \mathrm{ml}$ of Ultima Gold scintillation fluid (Packard) and counted with a Packard model 1900TR liquid scintillation analyzer to determine the specific activity of the probe.

DNA-DNA reassociation. Cross-reassociation studies were performed by using randomly selected smooth and rough strains. The unlabelled DNA solutions were brought to an $\mathrm{NaCl}$ concentration of $0.42 \mathrm{M}$ and sheared by sonication to give fragment sizes of approximately $500 \mathrm{bp}$. Each reaction mixture contained $0.5 \mathrm{ng}$ of labelled DNA and $5.8 \mu \mathrm{g}$ of unlabelled DNA. The total volume was adjusted to $50 \mu \mathrm{l}$ with $0.42 \mathrm{M} \mathrm{NaCl}$, and the preparation was layered with 100 $\mu$ l of mineral oil (catalog no. M-5904; Sigma). As negative controls, we used calf thymus DNA (catalog no. D-8661; Sigma) and $B$. fragilis DNA at the same concentration as the unlabelled DNAs from the $P$. micros strains. The DNA was denatured by boiling it for $10 \mathrm{~min}$. After this the vials were cooled to $0^{\circ} \mathrm{C}$. The reassociation reactions were carried out at $61.4^{\circ} \mathrm{C}$ for $72 \mathrm{~h}$. These optimum renaturation conditions were calculated by using the average $\mathrm{G}+\mathrm{C}$ content of $P$. micros given by Ezaki et al. (6) in the formulas published by Brenner and Falkow (2) and Gillis et al. (8).

To stop renaturation, the vials were cooled to $0^{\circ} \mathrm{C}$ again. S1 nuclease $(100 \mathrm{U} / \mathrm{ml})$ in a buffer containing $0.1 \mathrm{mM} \mathrm{ZnSO}_{4}$, $0.15 \mathrm{M} \mathrm{NaCl}, 30 \mathrm{mM}$ sodium acetate ( $\mathrm{pH} 4.5$ ), and $20 \mathrm{mg}$ of sheared and denatured calf thymus DNA per $\mathrm{ml}$ was added to all vials. The resulting mixture was incubated for $20 \mathrm{~min}$ at $50^{\circ} \mathrm{C}$, after which single nucleotides were removed by using Quick Spin columns containing Sephadex G-50. Samples of the reaction mixtures and of the void volumes of the columns were analyzed by using Ultima Gold scintillation fluid and a Packard liquid scintillation analyzer. The level of reassociation in each reaction mixture was determined as a percentage of the value for the homologous reaction corrected for the calf thymus DNA control.

Hydrophobicity. Cell surface hydrophobicity was assessed as described by Rosenberg et al. (28). Peptostreptococcus strains were grown on blood agar plates for $96 \mathrm{~h}$. Cultures were checked for purity by Gram staining and cultivation on blood agar plates. Cells were harvested by centrifugation at $4^{\circ} \mathrm{C}$ and $2,000 \times g$ and washed twice in phosphate-buffered saline (PBS). Bacterial suspensions were prepared in PBS to an optical density of $1.0(\lambda, 650 \mathrm{~nm})$. Duplicate $(3-\mathrm{ml})$ samples of each suspension were placed in test tubes.
Xylene was added to each suspension at concentrations of 0 , $2,4,8$, and $16 \%$. The tube contents were mixed for $45 \mathrm{~s}$ with a vortex mixer at the maximum setting. The aqueous and organic phases were allowed to separate for $30 \mathrm{~min}$, after which the aqueous phase was carefully removed with a Pasteur pipette and transferred to cuvettes. Contaminating xylene was allowed to evaporate for $60 \mathrm{~min}$. After this, each cuvette was vortexed for $1 \mathrm{~s}$ to resuspend the remaining bacteria. The level of absorption of the cells to the xylene droplets was calculated as the loss in optical density at 650 $\mathrm{nm}$ of the aqueous phase compared with the initial cell suspension, expressed as a percentage.

It is known that xylene can be cytotoxic. This might have influenced the results of the spectrophotometric assay described above. Therefore, we checked 12 strains $(6$ smooth morphotype strains and 6 rough morphotype strains) with the same method by using hexadecane (7.5 and $20 \%$ ) instead of xylene (28).

SDS-PAGE. SDS-PAGE profiles were obtained by using the PhastSystem (Pharmacia LKB Biotechnology, Uppsala, Sweden). Samples of soluble proteins were prepared as described by Slayne et al. (29). Cells from five blood agar plates which had been incubated for $96 \mathrm{~h}$ were harvested in $0.5 \mathrm{M}$ Tris- $\mathrm{HCl}(\mathrm{pH} 6.8)$. The cells were washed twice in the same buffer. After the final wash the cells were suspended in $200 \mu \mathrm{l}$ of a denaturation buffer containing $13.2 \mathrm{ml}$ of water, $1.2 \mathrm{ml}$ of glycerol, $4.8 \mathrm{ml}$ of $10 \%$ SDS, $1.2 \mathrm{ml}$ of $2-\beta-$ mercaptoethanol, $3.0 \mathrm{ml}$ of $0.5 \mathrm{M}$ Tris- $\mathrm{HCl}(\mathrm{pH} \mathrm{6.8)}$, and 1 $\mathrm{mg}$ of bromphenol blue per $\mathrm{ml}$. After the samples were heated for $10 \mathrm{~min}$ at $100^{\circ} \mathrm{C}$, the cell debris was removed by centrifugation at $16,000 \times g$ for $10 \mathrm{~min}$. Before SDS-PAGE the proteins in the supernatant were alkylated as described by Heukeshoven and Dernick (10). The running conditions used for the $12.5 \%$ homogeneous acrylamide gel were the conditions described by Slayne et al. (29). Low-molecularweight standard proteins were obtained from Pharmacia. The gels were silver stained manually as described by Morrissey (21).

Hemolysis. Cells were plated on agar plates containing heparinized blood from chickens, sheep, horses, rabbits, and humans (blood group $\mathrm{O}$ ). The plates were incubated in an anaerobic glove box, as described above. The plates were examined for hemolysis on days 7,17 , and 21 after inoculation.

Electron microscopy. For electron microscopic investigations, cells of strains HG 1179 and HG 1439 were incubated on an agar plate for $96 \mathrm{~h}$ or in a broth culture for $48 \mathrm{~h}$ and were harvested in PBS and washed in water once. The cells were then resuspended in water, negatively stained with $1 \%$ methylamine tungstate, and examined with a Philips model EM 301 electron microscope. All experiments were performed in duplicate with the same batch of cells and at least three times with independent batches of cells.

\section{RESULTS}

Two different $P$. micros morphotypes are described below; one produced smooth colonies on blood agar, and the other produced rough colonies. The cells of both types were gram-positive anaerobic cocci arranged in short chains and clumps. All strains were asaccharolytic and strongly peptidase positive on API preformed substrates.

The smooth morphotype was represented by the type strain and was characterized by small, dome-shaped, bright white, nonhemolytic colonies on horse blood agar plates (Fig. 1A). The rough morphotype was represented by clini- 

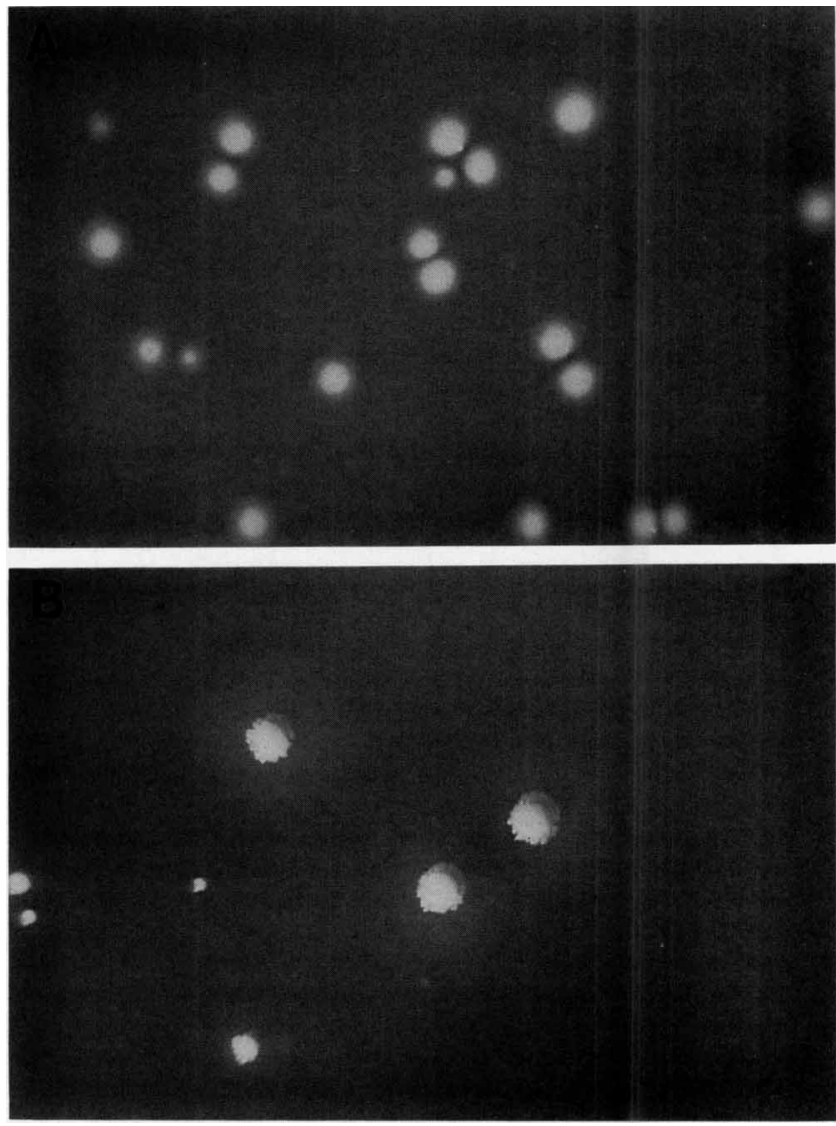

FIG. 1. (a) Characteristic smooth colonies of $P$. micros on a horse blood agar plate. (b) Characteristic rough colonies of $P$. micros on a horse blood agar plate. Magnification, $\times 80$.

cal isolates obtained from our laboratory and was characterized by equally white, dry, hemolytic colonies with wrinkled edges (Fig. 1B).

As shown in Table 1, the smooth and rough strains of $P$. micros exhibited high levels of DNA-DNA homology (64 to $132 \%$ ) when DNA from the type strain was used as the probe. When DNA from a rough strain was used as the

TABLE 1. Levels of reassociation between genomic DNAs and DNA from the $P$. micros type strain or a representative rough strain ${ }^{a}$

\begin{tabular}{llcc}
\hline \multicolumn{1}{c}{ Strain } & $\begin{array}{c}\text { Morpho- } \\
\text { type }\end{array}$ & $\begin{array}{c}\text { \% Reassociation with } \\
{\left[{ }^{3} \mathrm{H}\right] \mathrm{DNA} \text { from }} \\
\text { ATCC 33270 }\end{array}$ & $\begin{array}{c}\text { \% Reassociation with } \\
{\left[{ }^{\mathrm{T}} \mathrm{H}\right] \mathrm{DNA}} \\
\text { from HG 1439 }\end{array}$ \\
\hline ATCC 33270 & Smooth & 100 & 49 \\
HG 1451 & Smooth & 115 & 52 \\
HG 1454 & Smooth & 132 & 58 \\
HG 1459 & Smooth & 67 & 65 \\
HG 1468 & Rough & 79 & 99 \\
HG 1467 & Rough & 82 & 89 \\
HG 1439 & Rough & 64 & 100 \\
HG 1442 & Rough & 87 & 96 \\
HG 1257 & Rough & 77 & 103 \\
B. fragilis BE1 & & 0 & 7 \\
\hline
\end{tabular}

a Percentages were calculated by defining the value for the homologous reaction as $100 \%$ and the value for the reaction with calf thymus DNA as $0 \%$.

${ }^{b} \mathrm{~T}=$ type strain.
TABLE 2. Biochemical reactions of Peptostreptococcus species determined by using ATB-32A and API-ZYM kits ${ }^{a}$

\begin{tabular}{|c|c|c|c|c|}
\hline \multirow[b]{2}{*}{ Reaction } & \multicolumn{2}{|c|}{ P. micros } & \multirow[b]{2}{*}{$\begin{array}{c}P . \\
\text { magnus }\end{array}$} & \multirow[b]{2}{*}{$\begin{array}{c}P . \\
\text { anaerobiu }\end{array}$} \\
\hline & $\begin{array}{l}\text { Smooth } \\
\text { morpho- } \\
\text { type }\end{array}$ & $\begin{array}{l}\text { Rough } \\
\text { morpho- } \\
\text { type }\end{array}$ & & \\
\hline$\beta$-Glucosidase & $--^{b}$ & - & - & + \\
\hline Alkaline phosphatase & + & + & - & - \\
\hline Arginine arylamidase & + & + & + & - \\
\hline Proline arylamidase & V & V & - & + \\
\hline $\begin{array}{l}\text { Leucyl-glycine } \\
\text { arylamidase }\end{array}$ & V & V & + & - \\
\hline Phenylalanine arylamidase & + & + & - & - \\
\hline Pyroglutamic acid arylamidase & + & + & + & - \\
\hline Tyrosine arylamidase & + & + & \pm & - \\
\hline Alanine arylamidase & + & + & + & - \\
\hline Glycine arylamidase & + & + & + & - \\
\hline $\begin{array}{l}\text { Glutamic acid } \\
\text { decarboxylase }\end{array}$ & V & V & - & - \\
\hline$\alpha$-Fucosidase & V & V & - & - \\
\hline Histidine arylamidase & + & + & \pm & - \\
\hline $\begin{array}{l}\text { Glutamyl-glutamic } \\
\text { acid arylamidase }\end{array}$ & + & + & - & - \\
\hline Serine arylamidase & + & + & \pm & - \\
\hline
\end{tabular}

${ }^{a}$ Results are given only for reactions which discriminated between species.

${ }^{b}+$, positive reaction; - , negative reaction; $V$, variable reaction; \pm , weak reaction.

probe, the five rough strains gave reassociation values of 89 to $103 \%$, whereas the levels of reassociation with DNAs from the smooth strains were lower (49 to $65 \%)$. B. fragilis did not exhibit homology to both labelled strains of $P$. micros. In addition, the $P$. micros strains produced almost identical preformed enzyme profiles when the ATB-32A kit was used (Table 2). All smooth and rough strains were confirmed to be $P$. micros strains. All sugar reactions were negative, and the strains were strongly alkaline phosphatase positive. Most of the proteolytic reactions were positive; the exceptions were the proline arylamidase and leucyl-glycine arylamidase reactions, which were negative or weakly positive for some strains. This variability did not correspond with morphotype. Other Peptostreptococcus species produced profiles completely distinct from the profile of the $P$. micros strains (Table 2). When the API-ZYM kit was used, the two morphotypes produced identical enzyme profiles.

We checked the stability of the morphotypes of the strains. On blood agar plates, both morphotypes proved to be stable after more than 25 subcultures. All smooth morphotype strains remained smooth after four passages in Schaedler broth. All rough morphotype strains changed to a nonfibrillar type with a smooth colony morphology after one to four subcultures in Schaedler broth.

The cell surface hydrophobicities of three smooth and three rough strains were tested with four different concentrations of xylene (Fig. 2). At all concentrations, the smooth strains were more hydrophobic than the rough strains. Because the greatest differences between the smooth and rough morphotypes were found at a xylene concentration of $2 \%$, additional strains were tested at this concentration.

A significant difference between smooth and rough strains was found. The percentages of cells in the aqueous phase were $22 \% \pm 9 \%$ for the smooth strains and $70 \% \pm 7 \%$ for the rough strains (Table 3 ).

To eliminate the possible interference of the cytotoxic side effects of xylene, we measured hydrophobicities with hexa- 


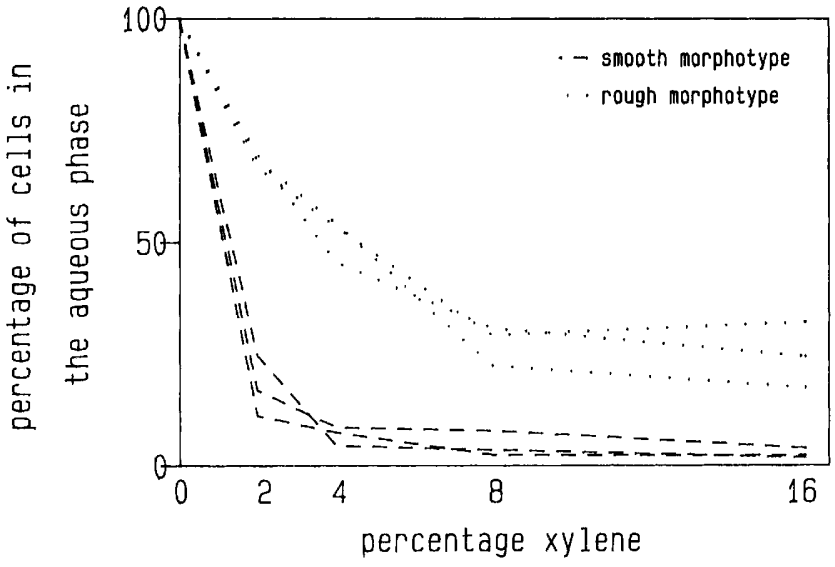

FIG. 2. Percentages of cells (i.e., turbidity at $650 \mathrm{~nm}$ compared with the control) in the aqueous phase after a two-phase partition test was performed.

decane as the organic phase at two different concentrations. As in the experiment performed with xylene, the smooth strains were hydrophobic, whereas the rough strains were relatively hydrophilic (Table 3 ).

Figure 3 shows SDS-PAGE profiles of representative strains of $P$. magnus, $P$. anaerobius, and the smooth and rough morphotypes of $P$. micros. The $P$. micros strains produced profiles that were clearly different from the profiles of the other Peptostreptococcus species tested. There were similarities between the profiles of the smooth and rough morphotypes of $P$. micros. However, there were bands that were unique for each morphotype. Minor differences among the strains of one group, especially among the smooth strains, were also observed.

The results of the hemolysis experiments are shown in Table 4. The smooth strains were not hemolytic except for limited activity on rabbit blood agar plates after 17 days. In contrast, the rough strains were hemolytic with a variety of erythrocytes. There were no noticeable differences in hemolysis between the different strains tested. Cells on chicken, horse, and rabbit blood agar plates were moderately positive after 7 days of incubation; after 21 days, the cells lysed human erythrocytes as well. Sheep erythrocytes were not attacked to any visible extent. Colony morphology and size were not influenced by the type of erythrocytes.

In electron micrographs all negatively stained strains

TABLE 3. Hydrophobicities of Peptostreptococcus species as determined by a two-phase partition test

\begin{tabular}{|c|c|c|c|c|}
\hline \multirow[b]{3}{*}{ Test conditions } & \multicolumn{4}{|c|}{ Hydrophobicity $(\%)^{a}$} \\
\hline & \multicolumn{2}{|c|}{ P. micros } & \multirow[b]{2}{*}{$\begin{array}{c}P . \text { magnus } \\
(n=1)\end{array}$} & \multirow[b]{2}{*}{$\begin{array}{c}P . \underset{(n=4)}{(n=4 i u s} \\
\text { anaerobius }\end{array}$} \\
\hline & $\begin{array}{c}\text { Smooth } \\
\text { morpho- } \\
\text { type } \\
(n=19)^{b}\end{array}$ & $\begin{array}{c}\text { Rough } \\
\text { morpho- } \\
\text { type } \\
(n=15)\end{array}$ & & \\
\hline $2 \%$ Xylene & $22 \pm 9$ & $70 \pm 7$ & 11 & $60 \pm 11$ \\
\hline $7.5 \%$ Hexadexane & $4 \pm 1$ & $40 \pm 6$ & $\mathrm{ND}^{c}$ & ND \\
\hline $20 \%$ Hexadecane & $5 \pm 1$ & $17 \pm 4$ & ND & ND \\
\hline
\end{tabular}

${ }^{a}$ Percentage of cells in the aqueous phase compared with the control. Mean \pm standard deviation.

${ }^{b} n$ is the number of strains studied.

${ }^{c} \mathrm{ND}$, not determined.

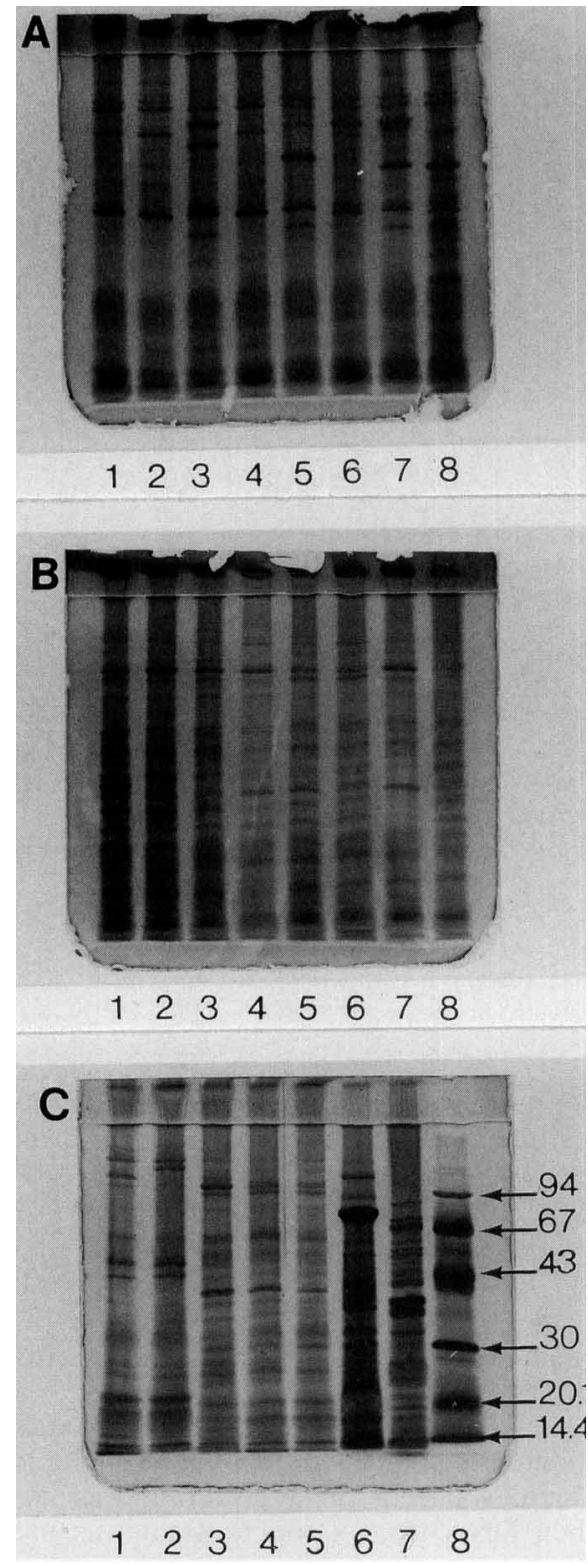

FIG. 3. SDS-PAGE patterns of different Peptostreptococcus species. (a) $P$. micros smooth morphotype. (b) $P$. micros rough morphotype. (c) Lanes 1 and 2, P. micros smooth morphotype; lanes 3 through 5, $P$. micros rough morphotype; lane 6, $P$. anaerobius; lane 7, P. magnus; lane 8 , marker (molecular weights $\left[\times 10^{3}\right]$ are indicated on the right).

exhibited the typical characteristics of gram-positive cells (Fig. 4). The cells of both morphotypes had thick cell walls. However, the cells of the rough morphotype had fibrillar structures, whereas the cells of the smooth morphotype did not. The fibrillar structures were long and appeared to aggregate with each other.

\section{DISCUSSION}

In this paper the results of a descriptive study of two morphotypes of $\boldsymbol{P}$. micros, isolated from subgingival plaque of periodontitis patients, are presented. Both types exhibited significant DNA reassociation with the DNA of the type 
TABLE 4 . Hemolysis of erythrocytes by $P$. micros morphotypes on agar plates

\begin{tabular}{lcllcc}
\hline \multirow{2}{*}{ Morphotype } & \multirow{2}{*}{$\begin{array}{c}\text { No. of strains } \\
\text { tested }\end{array}$} & $\begin{array}{c}\text { Origin of } \\
\text { erythrocytes }\end{array}$ & & \multicolumn{3}{c}{ Hemolysis after: } \\
\cline { 3 - 6 } Smooth & 4 & Chickens & $-^{a}$ & - & - \\
& & Sheep & - & - & - \\
& & Horses & - & - & - \\
& & Rabbits & - & $-{ }^{b}$ & $-{ }^{b}$ \\
& & Humans & - & - & - \\
Rough & 3 & Chickens & + & + & + \\
& & Sheep & - & - & - \\
& & Horses & $-/+$ & + & + \\
& & Rabbits & $-/+$ & + & + \\
& & Humans & - & - & + \\
\hline
\end{tabular}

${ }^{a}-$, no hemolysis; $-1+$, light zone around each colony; + , transparent zone around each colony.

${ }^{b}$ Erythrocytes were affected to a small extent.

strain. Therefore, we conclude that the smooth and rough strains belong to the same species (33). The reassociation data seemed to be more complex when DNA from a rough strain was used as the probe. Although the levels of reassociation with the other rough strains were approximately $100 \%$, the levels of reassociation with the DNAs of the smooth strains ranged from 49 to $65 \%$. The Gram stain reaction, anaerobic growth, and biochemical characteristics were identical for all strains.

Recently, the ATB-32A kit has been evaluated; the level of agreement between results obtained with this method and gas-liquid chromatography results was more than $99 \%$ (23). Therefore, we used this kit for identification of our strains. The profiles of preformed enzymes which we found with both ATB-32A and API-ZYM kits were identical to the profiles published previously $(6,15,23)$.

Adhesion (32) and phagocytosis (1) of bacteria are influenced by the hydrophobicity of the bacterial surface. Therefore, we measured the hydrophobicities of cells of the two morphotypes.

The smooth morphotype was hydrophobic, whereas the rough morphotype was relatively hydrophilic in tests performed with both xylene and hexadecane. Other methods used to determine bacterial cell surface hydrophobicity include measurement of the contact angle of water on a film of bacteria (22). In a pilot experiment, the rough strains had a smaller contact angle than the smooth strains, which confirmed the lower hydrophobicity of the rough strains (data not shown).

A number of studies in which bacteria were identified by SDS-PAGE have been performed. Slayne et al. (29) demonstrated the possibilities of the PhastSystem for this technique. We characterized the two morphotypes of $P$. micros and showed that with this method, it was possible to differentiate between the two morphotypes despite minor differences between strains of one group.

Colonies of $P$. micros have been reported to be nonhemolytic (11). We showed that this is true only for the smooth morphotype. The smooth morphotype strains lysed rabbit erythrocytes only after prolonged incubation. In contrast, the rough morphotype strains hemolyzed a variety of erythrocytes in a relatively short period of time. In particular, the nucleus-containing chicken erythrocytes were very sensitive to the rough strains. The sheep erythrocytes were not lysed to a visible extent.

In contrast to gram-negative bacteria, only a few gram-
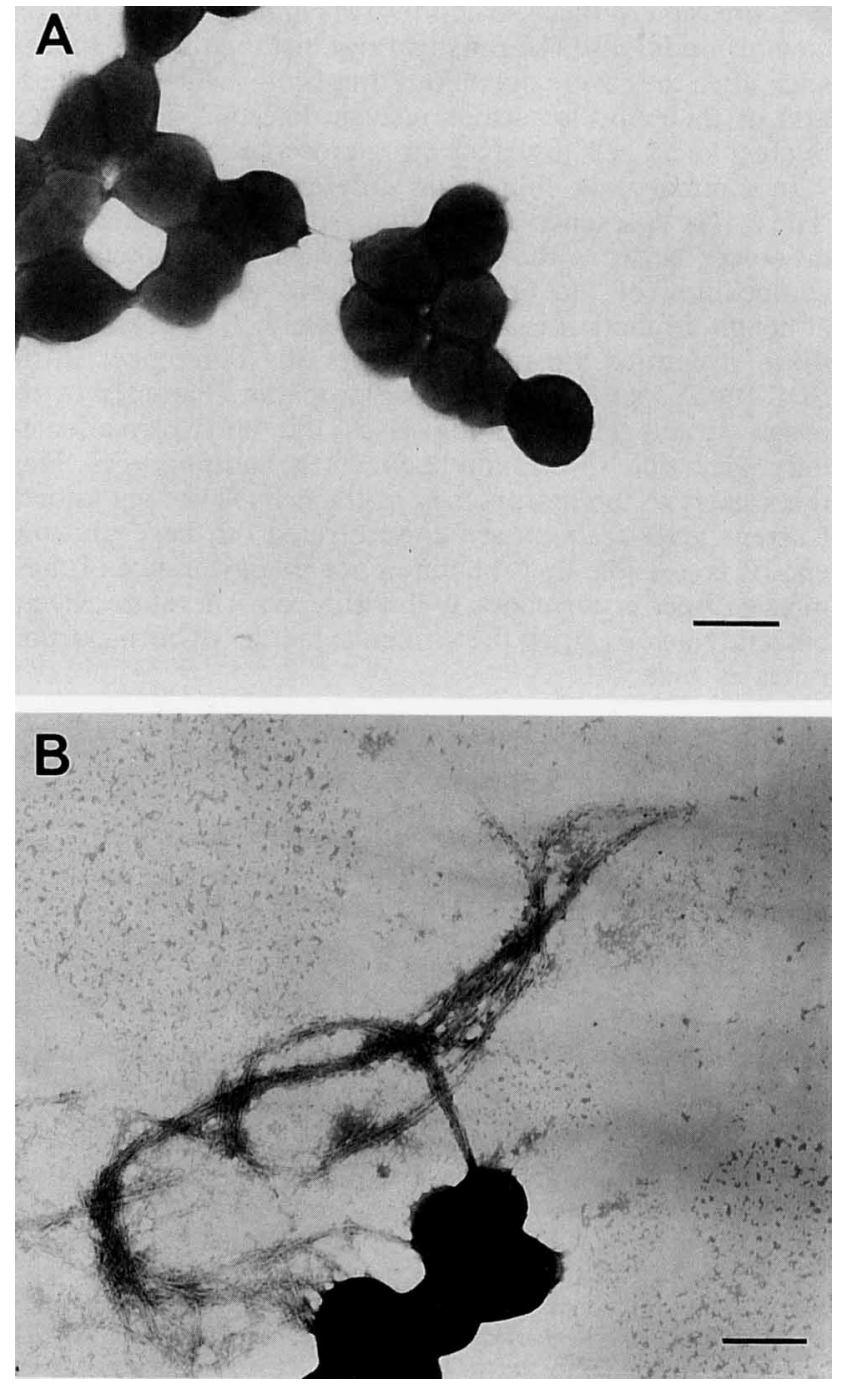

FIG. 4. Electron micrographs of negatively stained (1\% methylamine tungstate) cells of $P$. micros. (A) Smooth morphotype. (B) Rough morphotype. Magnification, $\times 21,750$. Bar $=0.4 \mu \mathrm{m}$.

positive bacteria are known to express fibrillar structures. Streptococcus sanguis, for example, has adhesins $(5,13)$, fibrillar glycoproteins (20), and cell surface components related to aggregation, adherence, and hydrophobicity (19). Streptococcus salivarius expresses three different classes of fibrils, which have distinct adhesive functions $(34,35)$. It has been suggested that subunits of the fibrils of these oral streptococci range in size from 70 to $90 \mathrm{kDa}(19)$ to more than $300 \mathrm{kDa}(20)$. These different fibrils have distinct hydrophobic characteristics. Their subunits are considerably larger than the subunits of fimbriae described for gramnegative bacteria (16). Fibrillar structures with a possible function in adherence have been described for Staphylococcus epidermidis as well (31).

We found fibrillar structures in $P$. micros rough morphotype strains when cells were negatively stained with methylamine tungstate. These structures were not seen on smooth morphotype cells. As far as we know, this is the first description of these structures in gram-positive anaerobic cocci. 
Expression of these structures was influenced by environmental conditions. The rough strains lost their rough appearance after they were subcultured in broth, which paralleled loss of their fibrillar structures, as determined with negatively stained cells by electron microscopy.

In summary, we found two different $P$. micros morphotypes. The presence of fibrillar structures is the major difference between the two morphotypes. The function and composition of the fibrillar structures are not clear yet, although a function in adhesion is likely. It is possible that these structures are responsible for the differences in the SDS-PAGE patterns and the hydrophilic character of the rough strains (19). Hemolysis is the only physiological difference which we found between the morphotypes. How this relates to the morphology of the cells is not yet known. Current investigations are concentrated on these phenomena. It is possible that the difference in appearance of these morphotypes is correlated with virulence. Therefore, we are currently investigating the virulence factors of both morphotypes as well.

\section{ACKNOWLEDGMENT}

We thank I. L. Eestermans (Department of Electron Microscopy, Vrije Universiteit, Amsterdam, The Netherlands) for taking the electron micrographs.

\section{REFERENCES}

1. Absolom, D. R. 1988. The role of bacterial hydrophobicity in infection: bacterial adhesion and phagocytic ingestion. Can. J. Microbiol. 34:287-298.

2. Brenner, D. J., and S. Falkow. 1971. Molecular relationships among members of the Enterobacteriaceae, p. 81-118. In E. W. Caspari (ed.), Advances in genetics. Academic Press, Inc., London.

3. Brook, I., S. Grimm, and R. B. Kielich. 1981. Bacteriology of acute periapical abscess in children. J. Endod. 7:378-380.

4. Dzink, J. L., S. S. Socransky, and A. D. Haffajee. 1988. The predominant cultivable microbiota of active and inactive lesions of destructive periodontal diseases. J. Clin. Periodontol. 15: 316-323.

5. Elder, B. L., and P. Fives-Taylor. 1986. Characterization of monoclonal antibodies specific for adhesion: isolation of an adhesin of Streptococcus sanguis FW213. Infect. Immun. 54: $421-427$.

6. Ezaki, T., N. Yamamoto, K. Ninomiya, S. Suzuki, and E. Yabuuchi. 1983. Transfer of Peptococcus indolicus, Peptococcus prevotii, and Peptococcus magnus to the genus Peptostreptococcus and proposal of Peptostreptococcus tetradius sp. nov. Int. J. Syst. Bacteriol. 33:683-698.

7. Garber, G. E., and A. W. Chow. 1989. Female genital tract infections, p. 429-459. In S. Finegold (ed.), Anaerobic infections in humans. Academic Press, Inc., London.

8. Gillis, M., J. De Ley, and M. De Cleene. 1970. The determination of molecular weight of bacterial genome DNA from renaturation rates. Eur. J. Biochem. 12:143-153.

9. Gorbach, S. L., and J. G. Barlett. 1974. Anaerobic infections. N. Engl. J. Med. 290:1177-1184, 1237-1245, 1289-1294.

10. Heukeshoven, J., and R. Dernick. 1988. Improved silver staining procedure for fast staining in PhastSystem development unit. I. Staining of sodium dodecyl sulfate gels. Electrophoresis 9:28 32.

11. Hillier, S., and B. J. Moncla. 1991. Anaerobic gram-positive nonsporeforming bacilli and cocci, p. 522-537. In A. Balows, W. J. Hausler, Jr., K. L. Herrmann, H. D. Isenberg, and H. J. Shadomy (ed.), Manual of clinical microbiology, 5th ed. American Society for Microbiology, Washington, D.C.

12. Ingham, H. R., J. B. Selkon, and C. M. Roxby. 1977. Bacterio- logical study of otogenic cerebral abscesses: chemotherapeutic role of metronidazole. Br. Med. J. 2:991-993.

13. Lamont, R. J., B. Rosan, C. T. Baker, and G. M. Nelson. 1988. Characterization of an adhesin antigen of Streptococcus sanguis G9B. Infect. Immun, 56:2417-2423.

14. Maiden, M. F. J., C. H. Lai, and A. Tanner. 1992. Characterization of oral gram-positive bacteria, p. 342-372. In J. Slots and M. A. Taubman (ed.), Contemporary oral microbiology and immunology. Mosby Year Book, Inc., St. Louis.

15. Marler, L. S. Allen, and J. Siders. 1984. Rapid enzymatic characterization of clinically encountered anaerobic bacteria with the API ZYM system. Eur. J. Clin. Microbiol. 3:294 300 .

16. McMichael, J. C., and J. T. Ou. 1979. Structure of common pili from Escherichia coli. J. Bacteriol. 138:969-975.

17. Moore, W. E. C. 1987. Microbiology of periodontal disease. J. Periodontal Res. 22:335-341.

18. Moore, W. E. C., L. V. Holdeman, E. P. Cato, R. M. Smibert, J. A. Burmeister, K. G. Palcanis, and R. R. Ranney. 1985. Comparative bacteriology of juvenile periodontitis. Infect. Immun. 48:507-519.

19. Morris, E. J., N. Ganeshkumar, M. Song, and B. C. McBride. 1985. Cell surface components of Streptococcus sanguis: relationship to aggregation, adherence, and hydrophobicity. J. Bacteriol. 164:255-262.

20. Morris, E. J., N. Ganeshkumar, M. Song, and B. C. McBride. 1987. Identification and preliminary characterization of a Streptococcus sanguis fibrillar glycoprotein. J. Bacteriol. 169:164 171.

21. Morrissey, J. G. 1981 . Silver stain for proteins in polyacrylamide gels. Anal. Biochem. 117:307-310.

22. Mozes, N., and P. G. Rouxhet. 1987. Methods for measuring hydrophobicity of microorganisms. J. Microbiol. Methods 6:99_ 112.

23. Murdoch, D. A., and I. J. Mitchelmore. 1991. The laboratory identification of gram-positive anaerobic cocci. J. Med. Microbiol. 34:295-308.

24. Murdoch, D. A., I. J. Mitchelmore, and S. Tabaqchali. 1988 Isolation of Peptostreptococcus micros from polymicrobial abscesses. Lancet i:594.

25. Oguntebi, B., A. M. Slee, J. M. Tanzer, and K. Langeland. 1982 Predominant microflora associated with human dental periapical abscesses. J. Clin. Microbiol. 15:964-966.

26. Rams, T. E., M. Andriolo, D. Feik, S. N. Abel, T. M. McGrivern, and J. Slots. 1991. Microbiological study of HIV-related periodontitis. J. Periodontol. 62:74-81.

27. Rams, T. E., D. Feik, M. A. Listgarten, and J. Slots. 1992. Peptostreptococcus micros in human periodontitis. Oral Microbiol. Immunol. 7:1-6.

28. Rosenberg, M., D. Gutnick, and E. Rosenberg. 1980. Adherence of bacteria to hydrocarbons: a simple method for measuring cell-surface hydrophobicity. FEMS Microbiol. Lett. 9:29-33.

29. Slayne, M. A., M. J. Aldred, and W. G. Wade. 1990. A rapid, semi-automated SDS-PAGE identification system for oral anaerobic bacteria. J. Appl. Bacteriol. 68:391-395.

30. Tanner, A., and H. Bouldin. 1989. The microbiota of early periodontitis lesions in adults. J. Clin. Periodontol. 16:467471.

31. Timmerman, C. P., A. Fleer, J. M. Besnier, L. de Graaf, F. Cremers, and J. Verhoef. 1991. Characterization of a proteinaceous adhesin of Staphylococcus epidermidis which mediates attachment to polystyrene, p. 87-103. In C. P. Timmerman (ed.), Staphylococcus epidermidis infections: virulence factors and host defence. Ph.D. thesis. Addix, Wijk bij Duurstede, The Netherlands.

32. van Loosdrecht, M. C. M., J. Lyklema, W. Norde, G. Shraa, and A. J. B. Zehnder. 1987. Electrophoretic mobility and hydrophobicity as a measure to predict the initial steps of bacterial adhesion. Appl. Environ. Microbiol. 53:1898-1901.

33. Wayne, L. G., D. J. Brenner, R. R. Colwell, P. A. D. Grimont, O. Kandler, M. I. Krichevsky, L. H. Moore, W. E. C. Moore, R. G. E. Murray, E. Stackebrandt, M. P. Starr, and H. G. Trüper. 1987. Report of the Ad Hoc Committee on Reconcilia- 
tion of Approaches to Bacterial Systematics. Int. J. Syst. Bacteriol. 37:463-464.

34. Weerkamp, A. H., P. S. Handley, A. Baars, and J. W. Slot. 1986. Negative staining and immunoelectron microscopy of adhesiondeficient mutants of Streptococcus salivarius reveal that the adhesive protein antigens are separate classes of cell surface fibril. J. Bacteriol. 165:746-755.
35. Weerkamp, A. H., H. C. van der Mei, and R. S. B. Liem. 1986. Structural properties of fibrillar proteins isolated from the cell surface and cytoplasm of Streptococcus salivarius $\left(\mathrm{K}^{+}\right)$cells and nonadhesive mutants. J. Bacteriol. 165:756-762.

36. Williams, B. L., G. F. McCann, and F. D. Schoenknecht. 1983. Bacteriology of dental abscesses of endodontic origin. J. Clin. Microbiol. 18:770-774. 